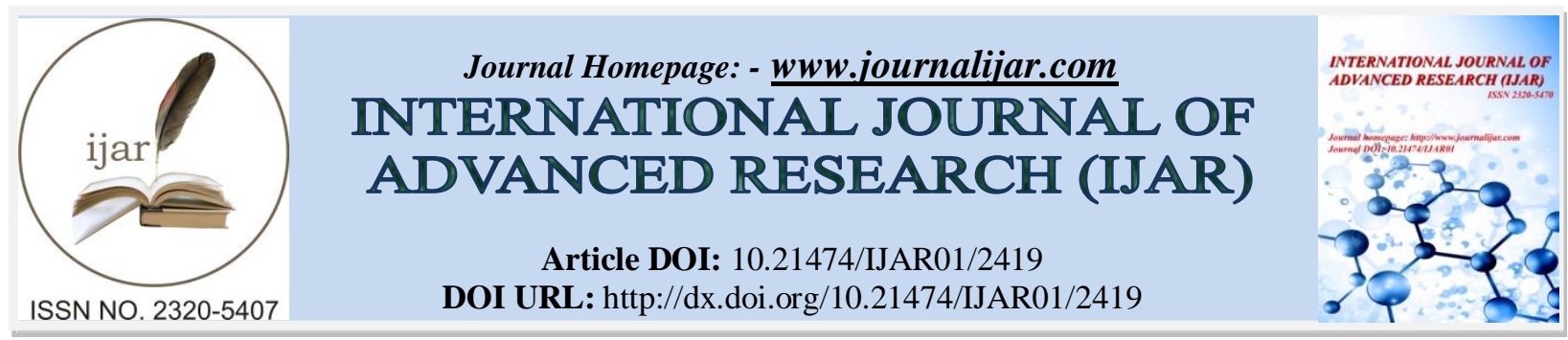

RESEARCH ARTICLE

\title{
EVALUATION OF RADIATION HAZARD INDICES DUE TO THE ROCK SAMPLES OF WESTERN GHATS OF SOUTH TAMILNADU.
}

M. Sheela Udhaya Roselin and G. Shanthi.

Department of Physics and Research Centre, Women's Christian College, Nagercoil, TamilNadu, India, 629001.

\section{Manuscript Info}

Manuscript History

Received: 20 October 2016

Final Accepted: 22 November 2016

Published: December 2016

Key words:-

Rock sample, gamma ray spectrometer, hazard indices

\section{Abstract}

Determination of the natural radioactivity has been carried out, by means of $\mathrm{NaI}(\mathrm{Tl})$ gamma ray spectrometer in rock samples collected from Western Ghats in south TamilNadu. Rocks in the study region are mainly used as construction materials. For the present study, the evaluation of environmental radioactivity and also estimation of the radiological parameters were carried out in the rock samples. Radiological parameters such as absorbed dose rate $\left(D_{R}\right)$, radium equivalent activity $\left(\mathrm{Ra}_{\mathrm{eq}}\right)$, hazard indices $\left(\mathrm{H}_{\mathrm{in}}\right.$ and $\left.\mathrm{H}_{\mathrm{ex}}\right)$ and radioactive level index $\left(\mathrm{I}_{\gamma}\right)$ were calculated to know the complete radiological hazardous nature. The range of activity concentration of ${ }^{238} \mathrm{U},{ }^{232} \mathrm{Th}$ and ${ }^{40} \mathrm{~K}$ were $0.44 \mathrm{~Bq} / \mathrm{kg}$ to $50.83 \mathrm{~Bq} / \mathrm{kg}, 0.211 \mathrm{~Bq} / \mathrm{kg}$ to $293.67 \mathrm{~Bq} / \mathrm{kg}$ and $233.49 \mathrm{~Bq} / \mathrm{kg}$ to $2091.70 \mathrm{~Bq} / \mathrm{kg}$ respectively. Concentration of radionuclide ${ }^{232} \mathrm{Th}$ and all the calculated radiological parameter are higher in site $\mathrm{L}_{22}$ due to the presence of Monazite and also higher than the world recommended level.

Copy Right, IJAR, 2016,. All rights reserved.

\section{Introduction:-}

Many areas in the world possess high levels of natural radiation. The high radiation levels are due to the presence of naturally occurring radioactive minerals in the rocks, soils, water, etc. Hence, humans should be aware of their natural environment with regard to the radiation health effects. Therefore now a days, human exposure to ionizing radiation is one of the scientific subjects that attracts public attention, since radiation of natural origin is responsible for most of the total radiation exposure of the human population (Ramasamy et al., 2013). The most important places among the well documented high natural background (NBR) areas of the world are Guarapuri in Brazil, Yangjiang in China and Chavara and Manavalakurichi in India (Singh et al., 2007). In India we have highbackground radiation areas along the South West coast. According to Paul and Gupta, the Monazite deposits occur throughout the erstwhile south Travancore region comprising parts of Kerala and Kanyakumari district, TamilNadu. The Presence of monazite deposits on the coastal areas of Kerala and TamilNadu is due to the weathering of rocks in Western Ghats (Shanthi et al., 2009), (Manigandan et al., 2014).

The radioactivity of rocks contributes to the external gamma dose rate that human receive from the environment (Rodrigo et al., 2009). Cosmic rays and terrestrial gamma rays are the two prominent contributors to the external radiation. The cosmic rays come from the celestial environment whereas terrestrial gamma rays come from the isotopes of ${ }^{238} \mathrm{U},{ }^{232} \mathrm{Th}$ and ${ }^{40} \mathrm{~K}$ present in the soil, rock, granites, and water etc (Kerur et al., 2010). The natural radioactivity depends mainly on geological and geographical conditions of the environment (Orgun et al., 2007).

Corresponding Author:- M. Sheela Udhaya Roselin.

Address:- Department of Physics and Research Centre, Women's Christian College, Nagercoil, 
Radioactivity is common in the rocks and soils that make up or planet, in the water in the oceans, and even in our building materials and homes. It is just everywhere (Uosif et al., 2015). Large variations in dose rates of both cosmic and terrestrial radiation are found depending on where the measurements are made. Measurements and studies of samples are very important to determine the amount of change of natural background activity with time as a result of any radioactive release.

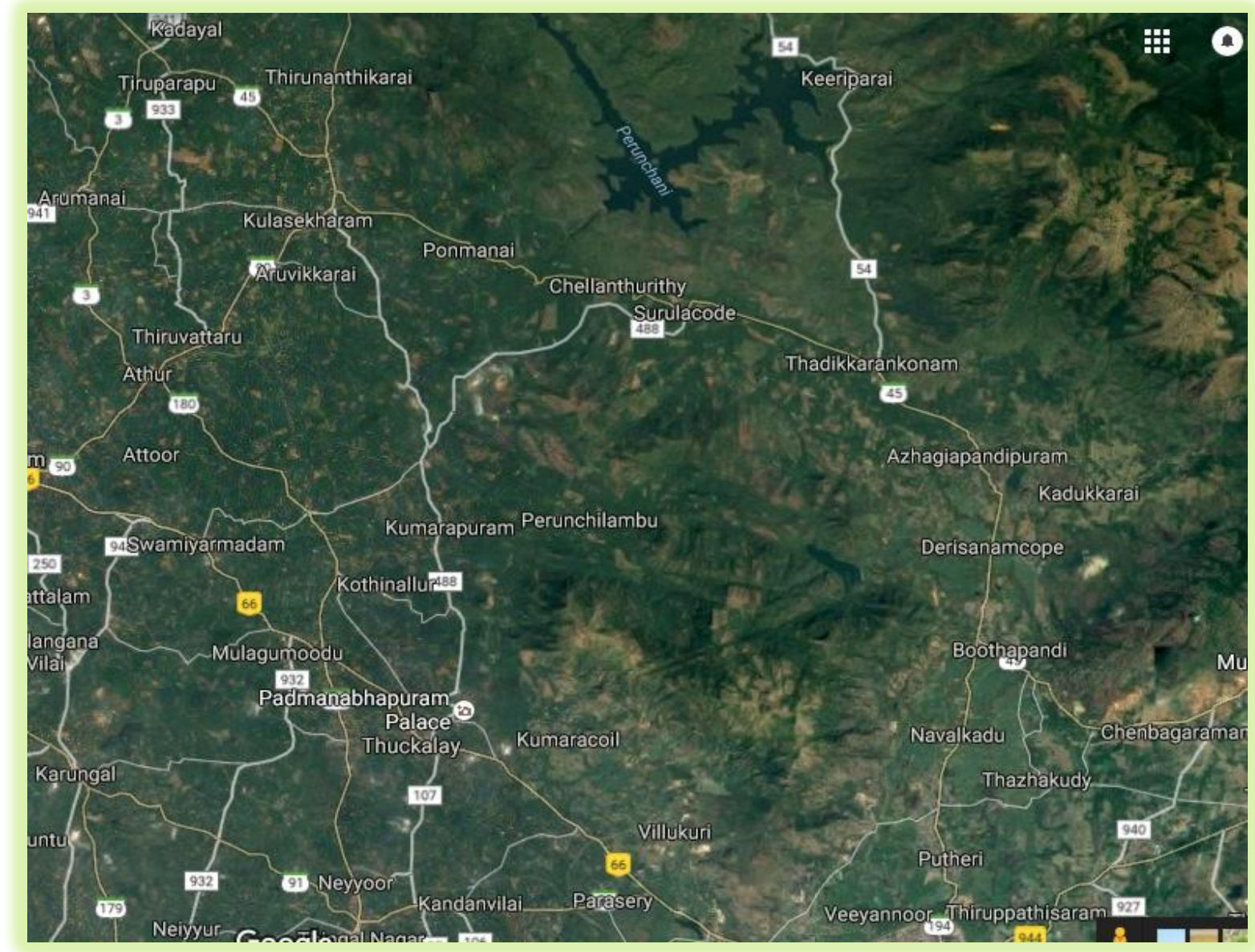

Fig 1:- Location of the study area.

Monitoring of any release of radioactivity to environment is important for environmental protection. Also natural radioactivity measurements are necessary not only due to its radiological impacts, but also because it acts as excellent biochemical and geochemical tracers in the environment. Therefore the assessment of radiation doses from natural radioactive sources is of particular importance as it is the largest contributor to the external dose of the world population (El-Taher et al., 2007).

Western Ghats (are also known as Sahyadi) is a mountain range that runs parallel to the western coast of the Indian peninsula located entirely in India. The range starts near the border of Gujarat and Maharashtra and runs through the states of Maharashtra, Goa, Karnataka, Kerala and TamilNadu ending at Kanyakumari at the tip of India (Google maps).

The main objective of this study is to: (i) determine the concentration of natural radionuclides $\left({ }^{238} \mathrm{U},{ }^{232} \mathrm{Th}\right.$ and $\left.{ }^{40} \mathrm{~K}\right)$ in the rocks of Western Ghats, India; (ii) Calculate the important radiological parameters to assess the complete radiological hazardous nature of the rocks.

\section{Sampling and Sample Preparation:-}

For the present study, rock samples were collected from 24 places of Western Ghats in Kanyakumari district and numbered as $\mathrm{L}_{1}$ to $\mathrm{L}_{24}$. Fig. 1 shows the location of the study area. Each sample nearly $1 \mathrm{~kg}$ in weight was washed in 
distilled water and dried in an oven at nearly $110^{\circ} \mathrm{C}$ to ensure that moisture was completely removed. About 250$300 \mathrm{~g}$ from each samples were crushed, homogenized, sieved, which is the optimum size enriched for heavy minerals. Weighted samples were placed in polyethylene beakers of $100 \mathrm{ml}$ volume each. The beakers were completely sealed for 4 weeks to reach secular equilibrium of the daughters with the parent (ASTM., 1983), (ASTM., 1986). After attainment of secular equilibrium each sample was counted for 2000s.

\section{Measurement:-}

The activity concentration of gamma ray emitting radionuclides was performed by high efficiency 5" x 5" NaI (Tl) Gamma Ray Scintillation Detector. Energy Calibration was done using Standard sources of known gamma ray energies and activities. The activities of various radionuclides were determined in $\mathrm{Bq} / \mathrm{kg}$ using the count spectra obtained from each of the samples. The main sources causing gamma radiations in rocks are Thorium $\left({ }^{232} \mathrm{Th}\right)$, Uranium $\left({ }^{238} \mathrm{U}\right)$ and Potassium $\left({ }^{40} \mathrm{~K}\right)$. The three characteristic gamma ray energies associated with these elements are $2.614 \mathrm{Mev}$ for Thorium, 1.764Mev for Uranium and 1.461Mev for Potassium (Verma et al.). The gamma ray spectrum was recorded using a computer based multi channel analyzer and processed using the TMCA32 software.

\section{Activity Concentrations of the Natural Radionuclides:-}

The activity concentrations of the natural radionuclides in the measured samples were computed using the relation (Uosif et al., 2015),

$$
\mathrm{A}(\mathrm{Bq} / \mathrm{kg})=\frac{N p}{e * \eta * m}
$$

Where Np is the net Gamma counting rate(sample counts- background counts) (counts per second), e is the abundance of the gamma line in a radionuclide, $\eta$ is the measured efficiency for each gamma line observed for the same number of channels either for the sample or the calibration source and $m$ is the mass of the sample in Kilograms.

\section{Radiological Parameters:-}

In the present study, the expected environmental impacts of the radionuclides are investigated in terms of Dose Rates, Radium Equivalent Activity External and Internal hazard indices and a radioactivity level index.

\section{Absorbed Dose Rate (nGy/h):-}

The Absorbed dose rate $\left(D_{R}\right)$ due to gamma ray emission from the main primordial radionuclides from the rock samples were evaluated using the formulae provided by United Nations Scientific Committee on Effect of Atomic Radiation (UNSCEAR, 2000).

In order to convert the activity concentration to absorbed dose rate in air $1 \mathrm{~m}$ above the ground surface for uniform distribution of naturally occurring radionuclides, dose coefficients of $0.92 \mathrm{nGy} / \mathrm{h}$ per Bq/kg for ${ }^{238} \mathrm{U}, 1.1 \mathrm{nGy} / \mathrm{h}$ per $\mathrm{Bq} / \mathrm{kg}$ for ${ }^{232} \mathrm{Th}$ and $0.080 \mathrm{nGy} / \mathrm{h}$ per Bq/kg for ${ }^{40} \mathrm{~K}$ were used (Mahur et al., 2008).

$\mathrm{D}_{\mathrm{R}}(\mathrm{nGy} / \mathrm{h})=0.462 \mathrm{C}_{\mathrm{U}}+0.604 \mathrm{C}_{\mathrm{Th}+} 0.0417 \mathrm{C}_{\mathrm{K}}$

Where $\mathrm{C}_{\mathrm{U}}$ is the activity concentration of ${ }^{238} \mathrm{U}, \mathrm{C}_{\mathrm{Th}}$ is the activity concentration of ${ }^{232} \mathrm{Th}$ and $\mathrm{C}_{\mathrm{K}}$ is the activity concentration of ${ }^{40} \mathrm{~K}$ in $\mathrm{Bq} / \mathrm{kg}$ and $\mathrm{D}_{\mathrm{R}}$ is the dose rate in $\mathrm{nGy} / \mathrm{h}$.

\section{Radium Equivalent Activity $\left(\mathbf{R a}_{\mathrm{eq}}\right)$ :-}

Radium equivalent activity is the quantity representative of external gamma radiation dose associated with the material. $\mathrm{Ra}_{\mathrm{eq}}$ compares the specific activities of samples containing different concentrations of ${ }^{238} \mathrm{U},{ }^{232} \mathrm{Th}$ and ${ }^{40} \mathrm{~K}$. It is evaluated using the equation (Beretka et al., 1985)

$\mathrm{Ra}_{\mathrm{eq}}=\mathrm{C}_{\mathrm{U}}+1.43 \mathrm{C}_{\mathrm{Th}}+0.077 \mathrm{C}_{\mathrm{K}} \leq 370 \mathrm{~Bq} / \mathrm{kg}$

Where $\mathrm{C}_{\mathrm{U}}$ is the activity concentration of ${ }^{238} \mathrm{U}, \mathrm{C}_{\mathrm{Th}}$ is the activity concentration of ${ }^{232} \mathrm{Th}$ and $\mathrm{C}_{\mathrm{K}}$ is the activity concentration of ${ }^{40} \mathrm{~K}$ in $\mathrm{Bq} / \mathrm{kg}$.

\section{The External and Internal Hazard Indices:-}

The external hazard index $\left(\mathrm{H}_{\mathrm{ex}}\right)$ was used to measure the external hazard due to the emitted gamma radiation. It was calculated by the equation (Tufail et al., 1992), $\mathrm{H}_{\mathrm{ex}}=\mathrm{C}_{\mathrm{U}} / 370+\mathrm{C}_{\mathrm{Th}} / 259+\mathrm{C}_{\mathrm{K}} / 4810 \leq 1 \mathrm{nGy} / \mathrm{h}$ 
Where $\mathrm{H}_{\mathrm{ex}}$ is the external hazard index in $n G y / h$ and $\mathrm{C}_{\mathrm{U}}$ is the activity concentration of ${ }^{238} \mathrm{U}, \mathrm{C}_{\mathrm{Th}}$ is the activity concentration of ${ }^{232} \mathrm{Th}$ and $\mathrm{C}_{\mathrm{K}}$ is the activity concentration of ${ }^{40} \mathrm{~K}$ in $\mathrm{Bq} / \mathrm{kg}$. The upper limit of this index is $\leq 1$ $\mathrm{nGy} / \mathrm{h}$.

The internal hazard index $\left(\mathrm{H}_{\text {in }}\right)$ was used to control the internal exposure to ${ }^{222} \mathrm{Rn}$ and its radioactive progeny. It was calculated by the equation (Tufail et al., 1992),

$\mathrm{H}_{\mathrm{in}}=\mathrm{C}_{\mathrm{U}} / 185+\mathrm{C}_{\mathrm{Th}} / 259+\mathrm{C}_{\mathrm{K}} / 4810 \leq 1 \mathrm{nGy} / \mathrm{h}$

Radioactive Level Index $\left(\mathbf{I}_{\gamma}\right)$ :-

The radioactivity level index is used to estimate the level of radiation risk, especially gamma rays associated with natural radionuclides in specific materials. It is defined as (Nuclear Energy Agency., 1979)

$\mathrm{I}_{\gamma}=\mathrm{C}_{\mathrm{U}} / 150+\mathrm{C}_{\mathrm{Th}} / 100+\mathrm{C}_{\mathrm{K}} / 1500 \leq 1 \mathrm{nGy} / \mathrm{h}$

Where $\mathrm{I} \gamma$ is the radioactivity level index and $\mathrm{C}_{\mathrm{U}}$ is the activity concentration of ${ }^{238} \mathrm{U}, \mathrm{C}_{\mathrm{Th}}$ is the activity concentration of ${ }^{232} \mathrm{Th}$ and $\mathrm{C}_{\mathrm{K}}$ is the activity concentration of ${ }^{40} \mathrm{~K}$ in $\mathrm{Bq} / \mathrm{kg}$. The safety value for this index is $\leq 1$.

\section{Results and Discussion:-}

Activity Concentration of Radionuclides

The activity concentration of radionuclides in the studied area is given in table.1. The activity concentration ranges for ${ }^{238} \mathrm{U}$, ${ }^{232} \mathrm{Th}$ and ${ }^{40} \mathrm{~K}$ are $0.44 \mathrm{~Bq} / \mathrm{kg}$ to $41.23 \mathrm{~Bq} / \mathrm{kg}$ with an average of $19.39 \mathrm{~Bq} / \mathrm{kg}, 0.21 \mathrm{~Bq} / \mathrm{kg}$ to $293.28 \mathrm{~Bq} / \mathrm{kg}$ with an average of $46.62 \mathrm{~Bq} / \mathrm{kg}$ and $233.49 \mathrm{~Bq} / \mathrm{kg}$ to $2091.70 \mathrm{~Bq} / \mathrm{kg}$ with an average of $1052.05 \mathrm{~Bq} / \mathrm{kg}$ respectively. The high radioactivity in the studied area was due to the presence of higher amount of zircon, iron oxides and other radioactive materials (El-Arabi et al., 2007). The distribution of ${ }^{238} \mathrm{U}$ and ${ }^{232} \mathrm{Th}$ are controlled by the presence of such these radioactive minerals (Cuney et al., 1987). Mean activity concentration is in the order ${ }^{238} \mathrm{U}<{ }^{232} \mathrm{Th}<{ }^{40} \mathrm{~K}$. Here concentration of ${ }^{40} \mathrm{~K}$ is very much higher than ${ }^{238} \mathrm{U}$ and ${ }^{232} \mathrm{Th}$. The activity concentration of ${ }^{238} \mathrm{U}$ is higher in 5 sampling sites, compared with the world average value $(33 \mathrm{~Bq} / \mathrm{kg})$. The activity concentration of ${ }^{232} \mathrm{Th}$ in 10 sampling sites is higher than world average value $(45 \mathrm{~Bq} / \mathrm{kg})$. The presence of these higher values clearly indicates that the rich distribution of heavy minerals in the study area (Ramasamy et al, 2013). Fig .2 shows the statistically significant correlation between the ${ }^{238} \mathrm{U}$ and ${ }^{232} \mathrm{Th}$ activity concentration.

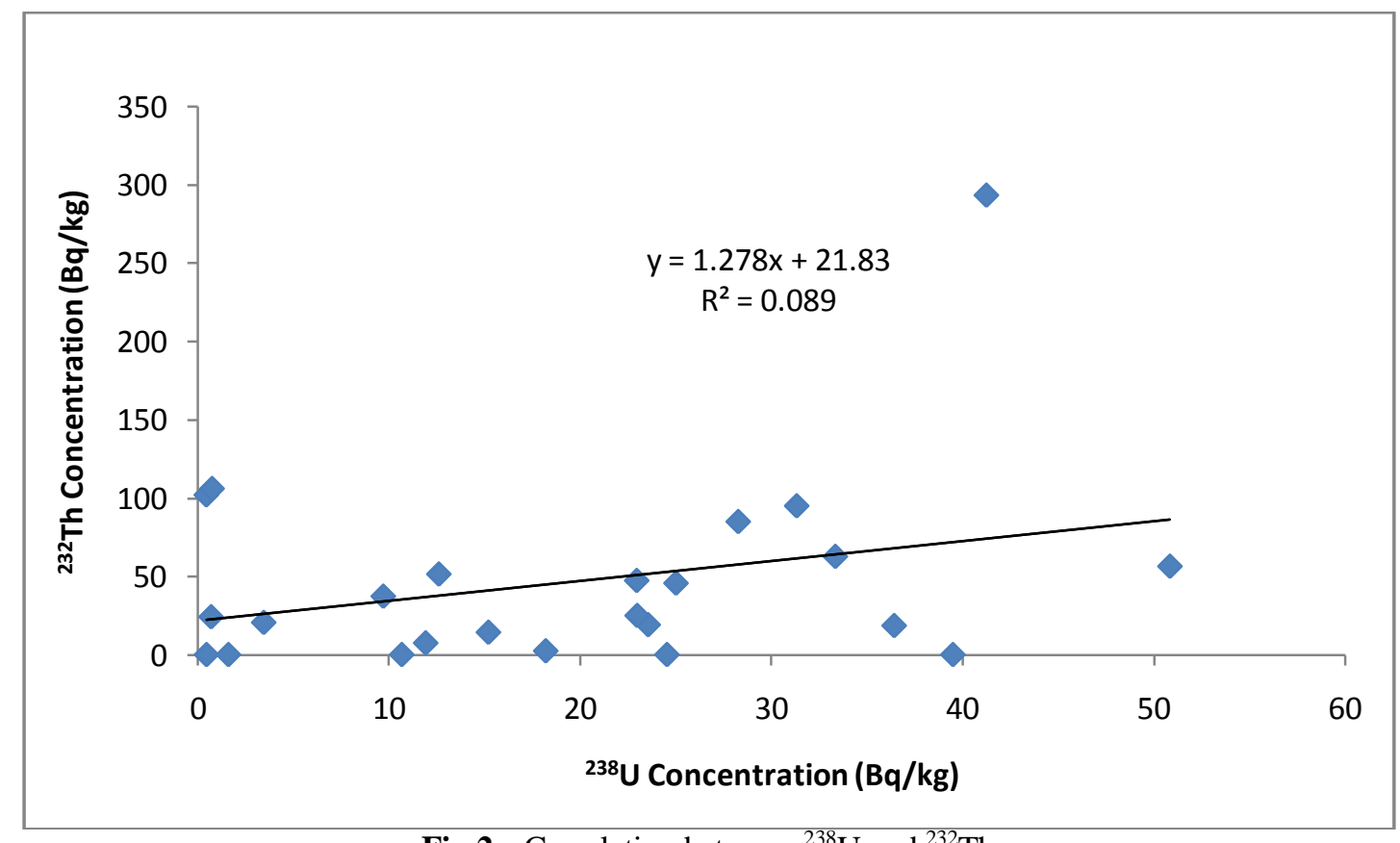

Fig 2:- Correlation between ${ }^{238} \mathrm{U}$ and ${ }^{232} \mathrm{Th}$ 
Table 1:- Activity Concentration of rock samples in different places.

\begin{tabular}{|c|c|c|c|c|}
\hline \multirow[t]{2}{*}{ Sl.No } & \multirow[t]{2}{*}{ Sample Location } & \multicolumn{3}{|c|}{ Activity Concentration $(\mathrm{Bq} / \mathrm{kg})$} \\
\hline & & ${ }^{238} \mathbf{U}$ & ${ }^{232} \mathrm{Th}$ & ${ }^{40} \mathbf{K}$ \\
\hline 1. & $\mathrm{~L}_{1}$ & $3.44 \pm 0.88$ & $20.75 \pm 0.98$ & $1660.48 \pm 2.44$ \\
\hline 2. & $\mathrm{~L}_{2}$ & $10.66 \pm 0.29$ & $0.22 \pm 0.05$ & $233.49 \pm 2.98$ \\
\hline 3. & $\mathrm{~L}_{3}$ & $22.95 \pm 0.25$ & $47.53 \pm 0.61$ & $801.97 \pm 2.35$ \\
\hline 4. & $\mathrm{~L}_{4}$ & $0.45 \pm 0.57$ & $0.211 \pm 0.07$ & $1033.67 \pm 1.77$ \\
\hline 5. & $\mathrm{~L}_{5}$ & $0.44 \pm 1.34$ & $102.22 \pm 1.84$ & $1362.07 \pm 2.44$ \\
\hline 6. & $\mathrm{~L}_{6}$ & $18.19 \pm 1.17$ & $2.61 \pm 0.65$ & $975.28 \pm 3.36$ \\
\hline 7. & $\mathrm{~L}_{7}$ & $9.7 \pm 1.56$ & $37.51 \pm 0.68$ & $1219.72 \pm 2.25$ \\
\hline 8. & $\mathrm{~L}_{8}$ & $0.74 \pm 0.38$ & $106.28 \pm 1.72$ & $1900.69 \pm 3.82$ \\
\hline 9. & $\mathrm{~L}_{9}$ & $36.41 \pm 1.09$ & $18.74 \pm 0.69$ & $1019.05 \pm 3.01$ \\
\hline 10. & $\mathrm{~L}_{10}$ & $24.99 \pm 1.22$ & $45.88 \pm 0.89$ & $507.41 \pm 2.25$ \\
\hline 11. & $\mathrm{~L}_{11}$ & $12.06 \pm 0.84$ & $51.66 \pm 2.06$ & $1007.76 \pm 4.74$ \\
\hline 12. & $\mathrm{~L}_{12}$ & $11.91 \pm 0.96$ & $7.66 \pm 0.41$ & $705.66 \pm 2.96$ \\
\hline 13. & $\mathrm{~L}_{13}$ & $33.333 \pm 0.96$ & $62.91 \pm 0.77$ & $1224.62 \pm 2.03$ \\
\hline 14. & $\mathrm{~L}_{14}$ & $28.25 \pm 1.15$ & $85.18 \pm 1.66$ & $987.82 \pm 2.75$ \\
\hline 15. & $\mathrm{~L}_{15}$ & $23.545 \pm 0.32$ & $19.29 \pm 0.91$ & $2091.7 \pm 4.19$ \\
\hline 16. & $\mathrm{~L}_{16}$ & $31.312 \pm 1.01$ & $95.24 \pm 1.69$ & $813.8 \pm 4.99$ \\
\hline 17. & $\mathrm{~L}_{17}$ & $50.83 \pm 0.15$ & $56.66 \pm 1.25$ & $746.02 \pm 3.97$ \\
\hline 18. & $\mathrm{~L}_{18}$ & $22.97 \pm 0.32$ & $25.18 \pm 1.21$ & $444.25 \pm 3.07$ \\
\hline 19. & $\mathrm{~L}_{19}$ & $15.19 \pm 0.79$ & $14.48 \pm 0.76$ & $864.55 \pm 2.59$ \\
\hline 20. & $\mathrm{~L}_{20}$ & $1.597 \pm 0.24$ & $0.21 \pm 0.41$ & $568.4 \pm 3.07$ \\
\hline 21. & $\mathrm{~L}_{21}$ & $0.692 \pm 0.14$ & $24.36 \pm 1.72$ & $1755.05 \pm 3.51$ \\
\hline 22. & $\mathrm{~L}_{22}$ & $41.23 \pm 1.47$ & $293.67 \pm 2.06$ & $1006.82 \pm 1.68$ \\
\hline 23. & $\mathrm{~L}_{23}$ & $39.481 \pm 0.51$ & $0.22 \pm 0.025$ & $1148.51 \pm 2.32$ \\
\hline 24. & $\mathrm{~L}_{24}$ & $24.527 \pm 0.78$ & $0.23 \pm 0.081$ & $1170.50 \pm 0.93$ \\
\hline
\end{tabular}

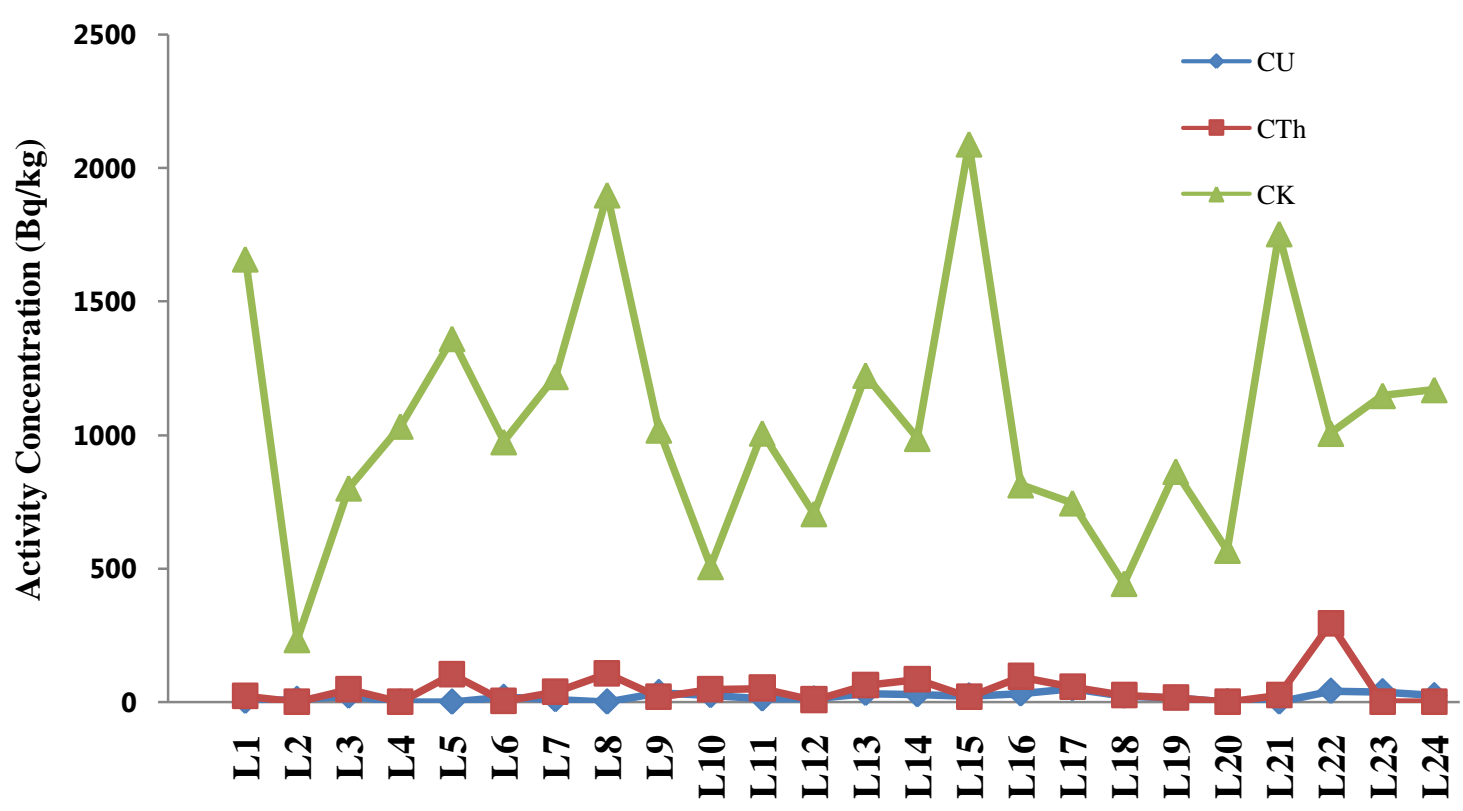

Sample Location

Fig 3:- Activity Concentration of ${ }^{238} \mathrm{U},{ }^{232} \mathrm{Th}$ and ${ }^{40} \mathrm{~K}$. 
The activity concentration of ${ }^{40} \mathrm{~K}$ is higher than the world average value (420 Bq/kg) (UNSCEAR, 2000). Among 24 sample locations, only one sample location is lower than the world average value. Among these three radionuclides

${ }^{40} \mathrm{~K}$ is more dominant in the studied area. This is due to the abundance of potassium is proportional to the silica content of the rocks (Ahmed et al., 2006), (Sannappa et al, 2010). Fig.3 shows the random distribution of radionuclides in the studied area.

\section{Radiological Parameters:-}

In order to know the radiological effect of the present study area, the different radiological indices are to be calculated and details of calculations are given in Table 2

Table 2:- Absorbed Dose Rate $\left(\mathrm{D}_{\mathrm{R}}\right)$, Radium Equivalent Activity $\left(\mathrm{Ra}_{\mathrm{eq}}\right)$, Hazard Indices $\left(\mathrm{H}_{\mathrm{in}}\right.$ and $\left.\mathrm{H}_{\mathrm{ex}}\right)$ Radioactive level Index $(\mathrm{I} \gamma)$.

\begin{tabular}{|c|c|c|c|c|c|}
\hline \multirow[b]{2}{*}{ Sample Location } & \multirow{2}{*}{$\begin{array}{c}\mathrm{D}_{\mathrm{R}} \\
(\mathrm{nGy} / \mathrm{h})\end{array}$} & \multirow{2}{*}{$\begin{array}{c}\mathrm{Ra}_{\mathrm{eq}} \\
(\mathrm{Bq} / \mathrm{kg})\end{array}$} & \multicolumn{2}{|c|}{ Hazard Indices $(\mathrm{nGy} / \mathrm{h})$} & \multirow[t]{2}{*}{$\left(\mathrm{I}_{\gamma}\right)$} \\
\hline & & & $\mathbf{H}_{\text {in }}$ & $\mathbf{H}_{\mathrm{ex}}$ & \\
\hline & & & & & \\
\hline $\mathrm{L}_{1}$ & 83.731 & 160.971 & 0.444 & 0.434 & 1.33 \\
\hline $\mathrm{L}_{2}$ & 14.800 & 28.957 & 0.108 & 0.078 & 0.228 \\
\hline $\mathrm{L}_{3}$ & 73.260 & 152.665 & 0.477 & 0.412 & 1.162 \\
\hline $\mathrm{L}_{4}$ & 43.544 & 80.346 & 0.218 & 0.216 & 0.694 \\
\hline $\mathrm{L}_{5}$ & 119.900 & 251.496 & 0.681 & 0.680 & 1.93 \\
\hline $\mathrm{L}_{6}$ & 50.737 & 97.021 & 0.313 & 0.262 & 0.797 \\
\hline $\mathrm{L}_{7}$ & 78.473 & 157.248 & 0.451 & 0.425 & 1.252 \\
\hline $\mathrm{L}_{8}$ & 145.045 & 299.075 & 0.809 & 0.809 & 2.334 \\
\hline $\mathrm{L}_{9}$ & 70.850 & 141.672 & 0.485 & 0.382 & 1.109 \\
\hline $\mathrm{L}_{10}$ & 60.877 & 129.673 & 0.420 & 0.350 & 0.963 \\
\hline $\mathrm{L}_{11}$ & 79.639 & 164.070 & 0.478 & 0.443 & 1.272 \\
\hline $\mathrm{L}_{12}$ & 39.688 & 77.222 & 0.242 & 0.208 & 0.626 \\
\hline $\mathrm{L}_{13}$ & 105.152 & 217.597 & 0.681 & 0.588 & 1.667 \\
\hline $\mathrm{L}_{14}$ & 106.586 & 226.120 & 0.691 & 0.611 & 1.698 \\
\hline $\mathrm{L}_{15}$ & 110.110 & 212.196 & 0.639 & 0.573 & 1.744 \\
\hline $\mathrm{L}_{16}$ & 106.897 & 230.167 & 0.709 & 0.622 & 1.703 \\
\hline $\mathrm{L}_{17}$ & 89.352 & 189.292 & 0.654 & 0.512 & 1.402 \\
\hline $\mathrm{L}_{18}$ & 44.596 & 93.185 & 0.316 & 0.252 & 0.701 \\
\hline $\mathrm{L}_{19}$ & 52.016 & 102.466 & 0.319 & 0.276 & 0.822 \\
\hline $\mathrm{L}_{20}$ & 24.624 & 45.669 & 0.127 & 0.123 & 0.391 \\
\hline $\mathrm{L}_{21}$ & 88.637 & 170.668 & 0.462 & 0.461 & 1.418 \\
\hline $\mathrm{L}_{22}$ & 241.366 & 538.707 & 1.570 & 1.459 & 3.882 \\
\hline $\mathrm{L}_{23}$ & 66.302 & 128.226 & 0.457 & 0.346 & 1.031 \\
\hline $\mathrm{L}_{24}$ & 60.347 & 114.978 & 0.379 & 0.311 & 0.946 \\
\hline
\end{tabular}

Table 3:- Comparison of Activity Concentrations with those found in Similar Studies.

\begin{tabular}{|l|c|c|c|c|c|c|}
\hline \multirow{2}{*}{ Country } & \multicolumn{3}{|c|}{ Activity(Bq/kg) } & \multirow{2}{*}{$\begin{array}{c}\mathrm{Ra}_{\mathrm{eq}} \\
(\mathrm{Bq} / \mathrm{kg})\end{array}$} & $\mathrm{I}_{\gamma}$ & Reference \\
\cline { 2 - 4 } & ${ }^{238} \mathbf{U}$ & ${ }^{232} \mathbf{T h}$ & ${ }^{40} \mathbf{K}$ & & & \\
\hline $\begin{array}{l}\text { Western Ghats } \\
\text { (Kanyakumari Dist) }\end{array}$ & $\mathbf{1 9 . 3 9}$ & $\mathbf{4 6 . 6 2}$ & $\mathbf{1 0 5 2 . 0 5}$ & $\mathbf{1 6 7 . 0 7}$ & $\mathbf{1 . 3}$ & This Study \\
\hline $\begin{array}{l}\text { Western Ghats } \\
\text { (Nilgiri District) }\end{array}$ & 26.26 & 53.61 & 231.93 & 118.6 & 1.47 & $\begin{array}{c}\text { ( Manigandan et al., } \\
\text { 2014) }\end{array}$ \\
\hline Azad Kashmir & 37.32 & 38.57 & 465.62 & 126.30 & - & (Rafique et al., 2014) \\
\hline India & 64 & 93 & 124 & 206.5 & 1.4 & (Singh et al.,2005) \\
\hline Algeria & 47.01 & 43 & 329 & 132 & 0.95 & (Wassila et al.,2011) \\
\hline Brazil & 1.69 & 5.32 & 34.15 & 12 & 0.1 & (Becegato et al.,2008) \\
\hline Egypt & 13.7 & 12.3 & 1233 & 126.2 & 1.04 & (Ahmed et al., 2005) \\
\hline Pakistan & 27.39 & 31.16 & 602.77 & 142.71 & 1.02 & (Akhtar et al., 2005) \\
\hline
\end{tabular}




\section{Absorbed Dose Rate (nGy/h)}

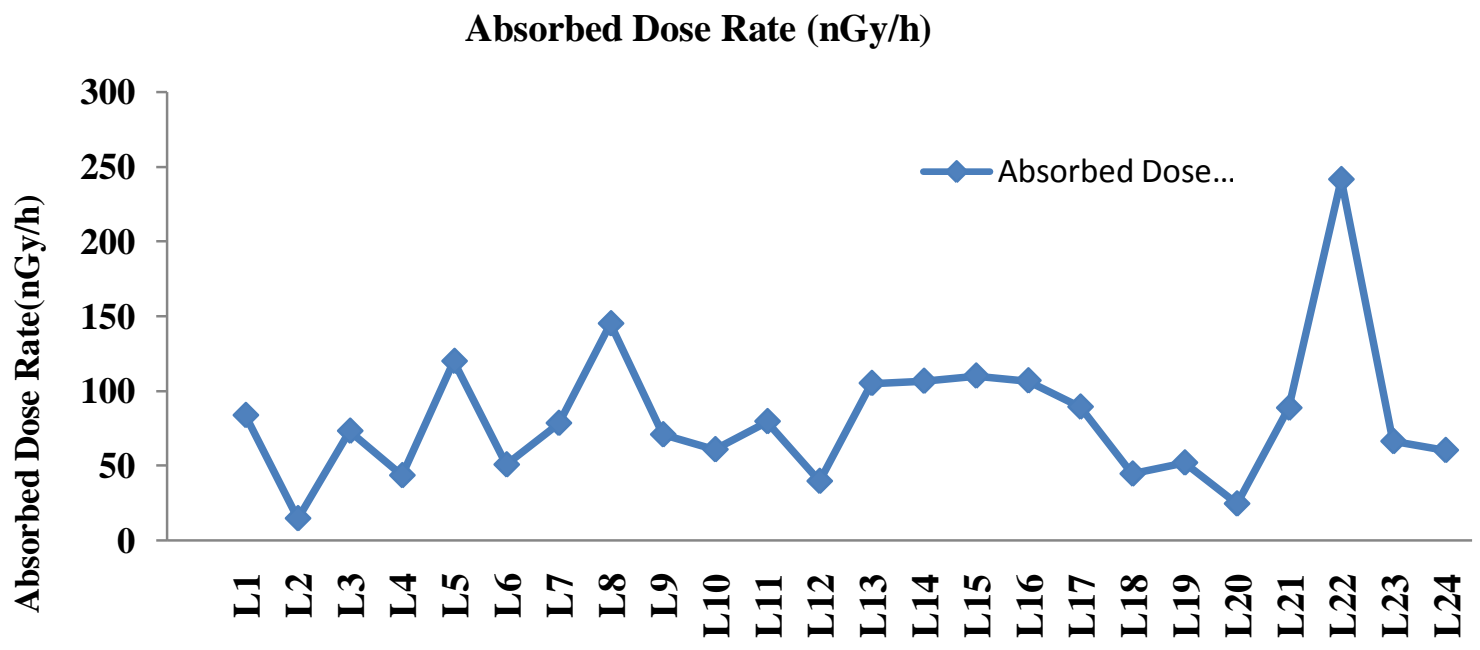

Sample Location

Fig 4:- Distribution of Absorbed Dose Rate

The calculated absorbed dose rate values were tabulated in Table.2. The calculated values are ranged from $14.80 \mathrm{nGy} / \mathrm{h}$ to $241.37 \mathrm{nGy} / \mathrm{h}$ with an average of $81.52 \mathrm{nGy} / \mathrm{h}$. The lower value was observed in sample location $\mathrm{L}_{2}$ $(14.80 \mathrm{nGy} / \mathrm{h})$, while the highest value was observed in $\mathrm{L}_{22}(241.37 \mathrm{nGy} / \mathrm{h})$. Only in 7 locations the absorbed dose rate is lower than the world average value $(57 \mathrm{nGy} / \mathrm{h})$, whereas the remaining 17 locations are much higher than the world average value. Fig. 4 shows the variation of absorbed doses in the sample locations.

\section{Radium Equivalent Activity (Bq/kg):-}

The Radium equivalent activity in $\mathrm{Bq} / \mathrm{kg}$ is tabulated in table.2. Radium equivalent activity values varied from 28.96 $\mathrm{Bq} / \mathrm{kg}$ to $538.70 \mathrm{~Bq} / \mathrm{kg}$ with an overall average value of $167.07 \mathrm{~Bq} / \mathrm{kg}$. From these results Raeq is relatively high at the sample location $\mathrm{L}_{22}(538.70 \mathrm{~Bq} / \mathrm{kg})$, which due to the higher concentration of ${ }^{232} \mathrm{Th}$. This value is higher than the recommended maximum value of world average $\quad 370 \mathrm{~Bq} / \mathrm{kg}$ (UNSCEAR., 2000).

\section{Radium Equivalent Activity(Bq/kg)}

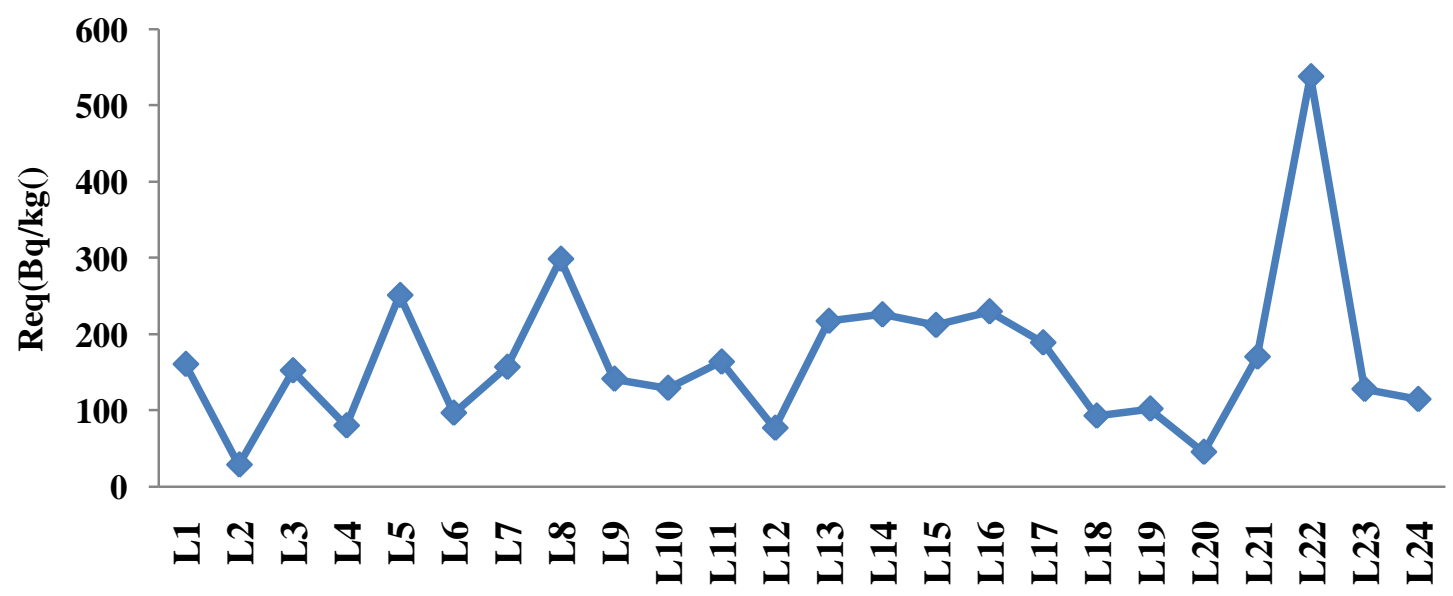

Sample Location

Fig 5:- Distribution of Radium Equivalent Activity

Fig. 5 shows the distribution of radium equivalent activity for the study area. On comparing with the values were measured in some other countries were lower than the calculated values of this work. Comparison table is shown in table.3. 


\section{Hazard Indices $\left(\mathrm{H}_{\mathrm{ex}}\right.$ and $\left.\mathrm{H}_{\mathrm{in}}\right)$ :-}

The Hazard indices of the rock samples in the studied area were also calculated. The objective of this calculation is to limit the radiation dose to permissible dose equivalent limit of $1 \mathrm{mSv} / \mathrm{y}$ (ICRP., 1990). The hazard indices values $\left(\mathrm{H}_{\mathrm{ex}}\right.$ and $\left.\mathrm{H}_{\mathrm{in}}\right)$ were tabulated in table.2. As given in table.2, Hex values varied from 0.08 to 1.46 with an average of 0.45 and Hin values were varied from 0.11 to 1.57 with an average of 0.51 .

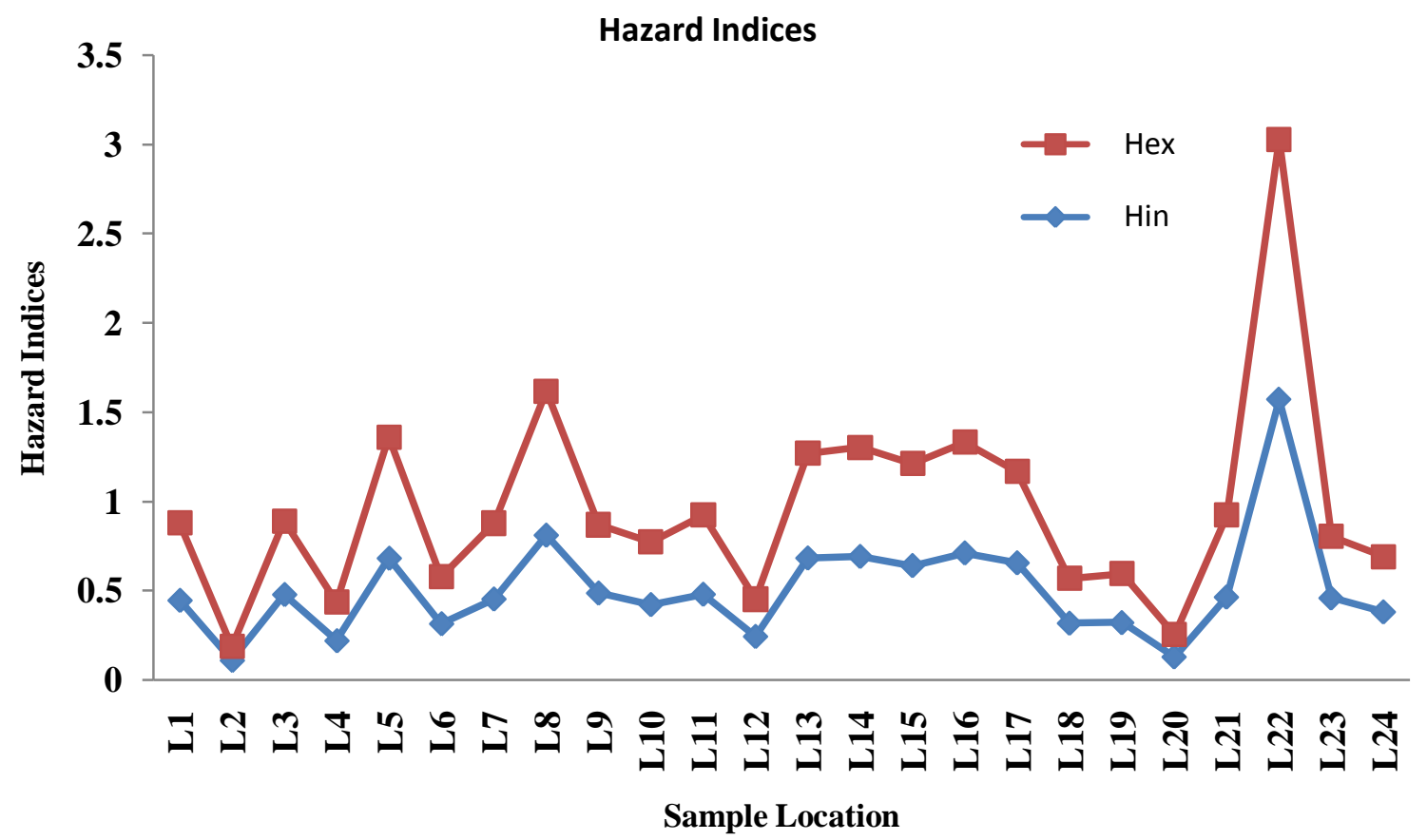

Fig 6:- Distribution of Hazard Indices.

Here $\mathrm{H}_{\mathrm{ex}}$ and $\mathrm{H}_{\text {in }}$ must not exceed the limit of unity for the radiation hazard to be negligible. But in our case one place $\mathrm{L}_{22}$ shows the Hex and $\mathrm{H}_{\text {in }}$ values higher than unity. Fig.6 shows the distribution of hazard indices for the sample locations.

\section{Radioactive level index $\left(\mathbf{I}_{\gamma}\right)$ :-}

Radioactive level index $\left(\mathrm{I}_{\gamma}\right)$ is used to estimate the level of a gamma radiation hazard associated with natural gamma ray emitters in the samples (Oladel et al., 2009). These values were tabulated in table.2. According to the data were given in table.2, the values varied from 0.23 to 3.88 with an average of 1.3. Here many places have shown the higher radioactive index than the safety level.

\section{Conclusion:-}

This study presents the activity concentration of ${ }^{238} \mathrm{U},{ }^{232} \mathrm{Th}$ and ${ }^{40} \mathrm{~K}$, absorbed dose rate, radium equivalent activity; hazard Indices and radioactive level index of rock samples from the selected regions of Western Ghats in south TamilNadu. The mean activity concentration of ${ }^{238} \mathrm{U},{ }^{232} \mathrm{Th}$ and ${ }^{40} \mathrm{~K}$ measured in this study were $19.39 \mathrm{~Bq} / \mathrm{kg}, 46.62$ $\mathrm{Bq} / \mathrm{kg}$ and $2091.70 \mathrm{~Bq} / \mathrm{kg}$ respectively. The activity concentration of ${ }^{40} \mathrm{~K}$ was highest in all the locations. The average value of absorbed dose rate was $81.562 \mathrm{nGy} / \mathrm{h}$ and radium equivalent activity was $167.07 \mathrm{~Bq} / \mathrm{kg}$. Hazard indices $\left(\mathrm{H}_{\mathrm{in}}\right.$ and $\left.\mathrm{H}_{\mathrm{ex}}\right)$ values in the study area were lower than the recommended values and the mean value of Hin and Hex were 0.51 and 0.45 respectively. Radioactive level index in the study area were varied from 0.23 to 3.88 with an average of 1.3. All the radiological parameters calculated in this study were below the recommended limits with the exception of one location. The only one location $\mathrm{L}_{22}$ were shown high radiological parameters than the world recommended values. Hence these results will use as a baseline data for rock samples of Western Ghats in south TamilNadu.

\section{References:-}

1. Ahmed, N.K., El-Arabi, A.G.M., 2005. Natural radioactivity in farm soil and phosphate fertilizer and its environmental implications in Qena governorate, Upper Egypt. J. Environ. Radioact. 84, 51-64. 
2. Ahmed, N.K., Abbady, A., El Arabi, A.M., El -Kamel, A.H., Abbady, A.G.E., 2006. Comparative study of the natural radioactivity of some selected rocks from Egypt and Germany, Indian Journal of Pure and Applied Physics. 44, 209-215.

3. Akhtar, N., Tufail, M., Ashraf, M., 2005. Natural environmental radioactivity and estimation of radiation exposure from saline soils. International Journal of Environmental Science \& Technology. 1, 279-285.

4. American Society for Testing Materials (Philadelphia, PA: ASTM, Annual Book of ASTM Standards ;( 04, 08)). 1986. Recommended practice for Investigation and Sampling Soil and Rock for Engineering Purposes for radionuclides. Report No. D, 420, 109-113.

5. American Society for Testing Materials, Standard method for sampling surface soils for radionuclides (Philadelphia, PA: ASTM). 1983. Report No. C, 983-998.

6. Becegato, V.A., Ferreira, F.J.F., Machado, W.C.P., 2008. Concentration of radioactivity elements derived from phosphate fertilizers in cultivated soils. Brazilian Archives of Biology and Technology. 51, 12551266.

7. Beretka, J., Matthew, P.J., 1985. Natural radioactivity of Australian building materials, Industrial wastes and byproducts. Health Physics, 48, 87-95.

8. Cuney, M., LeFort, P., Wangeg, Z., 1987. Geology of Granites and their Metallogenetic Relations. Science Press, Moscow. 852-873.

9. El-Arabi, A.M., 2007. ${ }^{226} \mathrm{Ra},{ }^{232} \mathrm{Th}$ and ${ }^{40} \mathrm{~K}$ Concentrations in igneous rocks from eastern desert, Egypt and its radiological implications. Radiation Measurements. 42, 94-100.

10. El-Taher, A., Uosif, M.A.M., Orab, A.A., 2007, Natural Radioactivity levels and Radiation Hazard Indices in Granite from Aswan to Wadi El-Allaqi Southeastern Desert, Egypt. Radiation Protection and Dosimetry. 124, 148-154.

11. ICRP 60.1990. Recommendations of the International Commission on Radiological Protection. ICRP Publication 60. Annals of the ICRP. Pergamon Press, Oxford, UK.

12. Kerur, B.R., Rajeshwari, T., Sharanabsappa., Anil Kumar, S., Narayan, K., Rekha, A., Haumaiah, B., 2010, Radioactivity levels in North Karnataka, India. Indian Journal of Pure\& Applied Physics. 48, 809-812.

13. Mahur, A.K., Rajesh Kumar., Sonkawade, R.G., Sengupta, D., Rajendra Prasad., 2008. Measurement of natural radioactivity and radon exhalation rate from rock samples of Jadukuda Uranium mines and its radiological implications. Nuclear Instruments and Methods in Physics Research B. 266, 1591-1597.

14. Manigandan, P.K., Chandar Shekar, B., 2014. Evaluation of Radionuclides in the Terrestrial Environment of Western Ghats. Journal of Radiation Research and Applied Sciences. 7, 310-316.

15. Nuclear Energy Agency, NEA-OECD. 1979. Exposure to Radiation from Natural Radioactivity in Building Materials. Report by NEA Group of Experts. OECD, Paris.

16. Oladeie Samuel Ajayi., 2009. Measurement of activity concentrations of ${ }^{40} \mathrm{~K},{ }^{226} \mathrm{Ra},{ }^{232} \mathrm{Th}$ for assessment of radiation hazards from soils of the southwestern region of Nigeria. Radiation Environ Biophysics. 48, 323332.

17. Orgun, Y., Altinsoy, N., Sahin, S.Y., Gngor, Y., Gultekin, A.H., Karahan, G., Karacik, Z., 2007. Natural and anthropogenic radionuclides in rocks and beach sands from Ezine region (Canakkale), Western Anatolia, Turkey. Applied Radiation and Isotopes. 65, 739-747.

18. Rafique, M., Khan, A.R., Jabbar, A., Rahman, S.U., Kazmi, S.J.A., Nasir, T., Arshed, W., Matiullah, 2014. Evaluation of radiation dose due to naturally occurring radionuclides in rock samples of different origins collected from Azad Kashmir. Russian Geology and Geophysics. 55, 1103-1112.

19. Ramasamy, V., Sundarrajan, M., Paramasivam, K., Meenakshisundram, V., Suresh, G., 2013. Assessment of spatial distribution and radiological hazardous nature of radionuclides in high background radiation area, Kerala, India. Applied Radiation and Isotopes. 73, 21-31.

20. Rodrigo O. Bastos, Carlos R. Appoloni. International Nuclear Atomic Conference- INAC 2009. Radioactivity of Rocks from the Geological Formations Belonging to the Tibagi River Hydrographic Basin.

21. Sannappa, J., Ningappa, C., Prakash Narasimha, K.N., 201). Natural Radioactivity levels n Granite Regions of Karnataka State. Indian Journal of Pure and Applied Physics. 48, 817-819.

22. Shanthi, G., Manian, C.G., Allan Gnana Raj, G., Thambi Thanka Kumaran, T., (2009). Radioactivity in Food Crops from High Background Radiation Area in Southwest India. Current Science. 97, 9.

23. Singh, S., Rani, A., Mahajan, R.K., 2005. $226 \mathrm{Ra},{ }^{232} \mathrm{Th}$ and ${ }^{40} \mathrm{~K}$ analysis in soil samples from some areas of Punjab and Himachal Pradesh, India using gamma ray Spectrometry. Radiation Measurements. 39, 431-439.

24. Singh, H.N., Shankar, D., Neelakandan, V.N., Singh, V.P., 2007. Distribution patterns of natural radioactivity and delineation of anomalous radioactive zones using in situ radiation observations in Southern Tamil Nadu, India. Journal of Hazardous Materials. 141, 264-272. 
25. Tufail, M., Ahmed, M., Shaib, S., Safdar, A., Mirza, N.M., Ahmed, N., Zafar, M.S., Zafar, F.I., 1992. Investigation of gamma-ray activity and radiological hazards of the bricks fabricated around Lahore, Pakistan. Pak. J. Sci. Ind. Res. 34, 216-220.

26. UNSCEAR. 2000). Effects and Risks of Ionizing Radiation. Report to the General Assembly with Annex B, United Nations. New York: United Nations Scientific Committee on Effects of Atomic Radiation.

27. Uosif, M.A.M., Shams, A.M,. Issa, Abd El-Salam, L.M,. (2015). Measurement of Natural Radioactivity n Granites and its Quartz-Bearing Gold at El-Fawakhir Area (Central Eastern Desert), Egypt. Journal of Radiation Research and Applied Sciences. 8, 393-398.

28. Verma, S.K,. Mital, G.S,. Rao, G.V, Rangarajan, R,. Reddy, K.N.S,. Venkatarayuda, M,. Radioactivity Measurements on Some Rock and Water Samples from Dakshin Gangotri, Antarctica. National Geophysical Research Institute, Hyderabad.

29. Wassila, B., \& Ahmed, B. (2011). The radioactivity measurements in soils and fertilizers using gamma spectrometry technique. Journal of Environmental Radioactivity. 1- 4.

30. www.Googlemaps.com 